\title{
Itraconazole: Precautions regarding drug interactions and bioavailability
}

\author{
MICHAEL PE PUTTICK MD FRCPC, PETER PHILLIPS MD FRCPC
}

\begin{abstract}
MPE PUtTick, P Phillips. Itraconazole: Precautions regarding drug interactions and bioavailability. Can J Infect Dis 1994;5(4):179-183.

OB.JEcTrve: To describe patients with fungal infections in whom drug interactions and bioavailability problems were associated with itraconazole treatment failure.

DESIGN: Retrospective chart review.

Setting: Two tertiary care university-affiliated teaching hospitals.

Population Studied: Itraconazole-treated patients between 1990 and 1992.

Marn REsults: Four patients treated with itraconazole were identified in whom suboptimal serum itraconazole levels were associated with relapse of disseminated histoplasmosis, treatment failure of invasive aspergillosis or development of superficial mycoses. Low serum itraconazole levels were associated with concurrent therapy with rifampin or agents inhibiting gastric acid secretion, with administration of itraconazole capsule contents through a nasogastric tube or with the presence of AIDS.

Conclusions: It is recommended that serum itraconazole levels be measured in patients with potentially life-threatening mycoses if coexistent factors may interfere with itraconazole therapy.
\end{abstract}

Key Words: Drug interactions, Invasive mycoses, Itraconazole levels

\section{Itraconazole : Précautions quant aux interactions médicamenteuses et à la biodisponibilité}

OвJестіF : Décrire des patients atteints de mycoses chez qui les interactions médicamenteuses et les problèmes de biodisponibilité ont été associés à l'échec d'un traitement par itraconazole.

Modèle : Analyse rétrospective des dossiers.

Contexte : Deux centres hospitaliers universitaires de soins tertiaires

Population Étudiée : Patients traités par itraconazole entre 1990 et 1992.

Principaux Résultats : Quatre patients traités par itraconazole ont été identifiés. Chez ces sujets, des taux sériques d'itraconazole sous-optimaux ont été associés à une rechute de l'histoplasmose disséminée, à un échec thérapeutique face à une aspergillose invasive ou au développement de mycoses superficielles. Les taux sériques faibles d'itraconazole ont été associés à un traitement concomitant par rifampine ou par agents inhibiteurs de la sécrétion d'acide gastrique avec l'administration du contenu de la capsule d'itraconazole par sonde nasogastrique ou en présence de SIDA.

Conclusions : Il est recommandé que les taux sériques d'itraconazole soient mesurés chez les patients porteurs de mycoses à potentiel fatal, si des facteurs concomitants risquent de nuire au traitement par itraconazole.

Department of Medicine, St Paul's Hospital, and Division of Infectious Diseases, University of British Columbia, Vancouver, British Columbia

Correspondence and reprints: Dr P Phillips, Department of Medicine, St Paul's Hospital, 1081 Burrard Street, Vancouver, British Columbia V6Z 1Y6. Telephone (604) 631-5317. Fax (604) 631-5210

Received for publication October 14, 1993. Accepted February 1, 1994 
A MPHOTERICIN B HAS BEEN THE MAINSTAY OF TREATMENT for invasive mycoses since its introduction in 1956; however, it must be given intravenously, and adverse effects are common (1). Since the late 1970s, a number of orally administered azole antifungal agents, including ketoconazole, fluconazole and itraconazole, has been developed, and they offer therapeutic alternatives to amphotericin B for certain mycoses (2). Itraconazole is a recently licensed triazole that is well tolerated (2-4) and has broad spectrum antifungal activity $(2,5)$. Clinical trials have shown encouraging results in the treatment of aspergillosis $(6,7)$, histoplasmosis (8), and other systemic and superficial mycoses (3,9-12). Its tolerance and efficacy indicate that it will be an important addition to antifungal chemotherapy.

Drug interactions resulting in suboptimal serum azole levels and failed therapy have been a greater problem with ketoconazole than with fluconazole (1315). That such problems also complicate itraconazole therapy may not be widely appreciated, despite a recent report (16). There have been few other reports of drug interactions or other factors associated with low serum itraconazole levels and treatment failures. Four patients are presented in whom drug interactions or other factors resulted in enhanced metabolism or reduced bioavailability of itraconazole, possibly resulting in diminished clinical efficacy.

\section{PATIENTS AND METHODS}

Itraconazole was an investigational drug in Canada until late 1993. In the present study, four patients were identified in whom suboptimal to unmeasurable serum itraconazole levels were documented. All were treated with itraconazole at university teaching hospitals in Vancouver, British Columbia between August 1991 and December 1992. Patients were instructed to take itraconazole capsules with meals. Itraconazole levels in all patients were measured by selective bioassay or high performance liquid chromatography (Michael Rinaldi, PhD, Mycology Testing Laboratory, Audie Murphy VA Hospital, San Antonio, Texas), and were obtained in all but one case approximately $4 \mathrm{~h}$ after the previous dose. The first level in patient 3 was obtained $18 \mathrm{~h}$ after the previous dose on day 14 of itraconazole therapy.

Patients' medical records were examined in detail and the following data extracted: age and sex of patient, underlying disease, fungal infection, site and method of diagnosis, other infections, dosage and route of administration of itraconazole, duration of therapy and timing of serum levels, concurrent medications with dosages and clinical course.

\section{RESULTS}

Patient characteristics and itraconazole levels are summarized in Table 1.

Case histories - Case one: A 45-year-old man with AIDS presented with constitutional symptoms, anemia, rash and hepatosplenomegaly. Disseminated histoplasmosis and Mycobacterium avium infection were diagnosed from blood cultures. Remission of the histoplasmosis was induced with a cumulative dose of $1.4 \mathrm{~g}$ amphotericin $\mathrm{B}$, followed by maintenance therapy with itraconazole $400 \mathrm{mg} /$ day. The $M$ avium infection was treated with rifampin, ethambutol, clofazamine and ciprofloxacin. The patient presented again three months later with a blood culture-documented relapse of disseminated histoplasmosis and was noted to have extensive thrush. A serum itraconazole level was unmeasurable. Itraconazole was discontinued, and he was re-treated with amphotericin B. During amphotericin B maintenance therapy ( $1 \mathrm{mg} / \mathrm{kg}$ once weekly), the patient experienced a second relapse of histoplasmosis. Itraconazole $400 \mathrm{mg} /$ day was restarted, and rifampin was discontinued. No other medications were changed. Three days later, a serum itraconazole level was $1.2 \mu \mathrm{g} /$ mL. During the subsequent six months the patient remained clinically free from histoplasmosis. Itraconazole was then discontinued because of persistent thrush, which was also poorly responsive to oral fluconazole and topical amphotericin B. He died seven months later of an acute encephalopathy of uncertain etiology, and an autopsy was not performed.

Case two: A 58-year-old man with AIDS and disseminated Mycobacterium kansasii infection developed biopsy- and culture-proven extrapulmonary histoplasmosis of the right nostril. A cumulative dose of $1 \mathrm{~g}$ amphotericin B was associated with resolution of the nasal lesion. This was followed by maintenance therapy with itraconazole $400 \mathrm{mg} /$ day. The patient was receiving concurrent rifampin, isoniazid and ethambutol. Thrush and dermatophytosis developed after seven months of itraconazole therapy. A serum itraconazole level was unmeasurable. Rifampin was discontinued, and after three days a repeat serum itraconazole level was $0.9 \mu \mathrm{g} / \mathrm{mL}$. The superficial mycoses resolved, and the patient remained free from histoplasmosis relapse until his death from staphylococcal septicemia nine months later. Persistent thrush developed one month before death, and did not respond to fluconazole.

Case three: A 31-year-old man with AIDS and invasive pulmonary aspergillosis diagnosed by percutaneous needle aspirate was initially treated with amphotericin B $80 \mathrm{mg}$ intravenously three times weekly, with partial response. Neutrophil count at the onset of symptoms was $0.5 \times 10^{9} / \mathrm{L}$. Itraconazole $400 \mathrm{mg} /$ day was started and amphotericin was continued in addition until adequate absorption was documented by serum levels. The patient was receiving multiple other medications including omeprazole $20 \mathrm{mg}$ / day and antacids as needed. The highest itraconazole serum level at steady state was $0.42 \mu \mathrm{g} / \mathrm{mL}$. Despite increase in the itraconazole dose to $800 \mathrm{mg} /$ day, continuation of amphotericin $\mathrm{B}$ and stopping omeprazole and antacids, progressive disease with pulmonary cavitation and intractable chest wall 
TABLE 1

Summary of patient characteristics

\begin{tabular}{|c|c|c|c|c|c|c|c|c|c|}
\hline \multirow[b]{2}{*}{ Case } & \multirow[b]{2}{*}{$\begin{array}{l}\text { Age/ } \\
\text { Sex }\end{array}$} & \multirow[b]{2}{*}{$\begin{array}{l}\text { Fungal } \\
\text { infection }\end{array}$} & \multirow[b]{2}{*}{$\begin{array}{l}\text { Underlying } \\
\text { disease }\end{array}$} & \multirow[b]{2}{*}{ Other drugs } & \multirow[b]{2}{*}{$\begin{array}{l}\text { Itraconazole } \\
\text { dose/route }\end{array}$} & \multicolumn{3}{|c|}{ Timing of levels ${ }^{\dagger}$} & \multirow[b]{2}{*}{ Outcome } \\
\hline & & & & & & Levels $(\mu \mathrm{g} / \mathrm{mL})$ & $\begin{array}{c}\text { Duration } \\
\text { (days) }\end{array}$ & $\begin{array}{c}\text { Post- } \\
\text { dose (h) }\end{array}$ & \\
\hline 1 & $45 \mathrm{M}$ & $\begin{array}{l}\text { Disseminated } \\
\text { histoplasmosis }\end{array}$ & AIDS & Rifampin & $\begin{array}{c}400 \text { mg/day } \\
\text { by mouth }\end{array}$ & $\begin{array}{l}0 \text { (on RMP) } \\
1.2 \text { (off RMP) }\end{array}$ & $\begin{array}{r}90 \\
3\end{array}$ & $\begin{array}{l}4 \\
4\end{array}$ & $\begin{array}{l}\text { Histoplasmosis } \\
\text { relapse, } \\
\text { development of } \\
\text { thrush }\end{array}$ \\
\hline 2 & $58 \mathrm{M}$ & $\begin{array}{r}\text { Extrapulmonary } \\
\text { histoplasmosis }\end{array}$ & AIDS & Rifampin & $\begin{array}{l}400 \mathrm{mg} / \mathrm{day} \\
\text { by mouth }\end{array}$ & $\begin{array}{c}0 \text { (on RMP) } \\
0.9 \text { (off RMP) }\end{array}$ & $\begin{array}{r}210 \\
3\end{array}$ & $\begin{array}{l}4 \\
4\end{array}$ & $\begin{array}{l}\text { Development of } \\
\text { thrush and } \\
\text { dermatophytosis }\end{array}$ \\
\hline \multirow[t]{2}{*}{3} & $31 \mathrm{M}$ & $\begin{array}{l}\text { Invasive } \\
\text { aspergillosis }\end{array}$ & AIDS & $\begin{array}{c}\text { Omeprazole, } \\
\text { antacids }\end{array}$ & $\begin{array}{c}400 \text { mg/day } \\
\text { by mouth }\end{array}$ & $\begin{array}{l}0.42 \\
0.23\end{array}$ & $\begin{array}{l}14 \\
49\end{array}$ & $\begin{array}{r}18 \\
4\end{array}$ & Death* \\
\hline & & & & & $\begin{array}{l}800 \text { mg/day } \\
\text { by mouth }\end{array}$ & 0.53 & $28^{\ddagger}$ & 4 & \\
\hline
\end{tabular}

ALL Acute lymphoblastic leukemia; BMT Bone marrow transplantation; *Failed therapy with amphotericin followed by itraconazole; ${ }^{\dagger}$ Length of time (days) after starting itraconazole, time (hours) of collection after last dose; ${ }^{*}$ Level taken four weeks after dose increased

pain developed. A serum itraconazole level after one month of $800 \mathrm{mg} /$ day was $0.53 \mu \mathrm{g} / \mathrm{mL}$. Death followed several months of general deterioration.

Case four: A 32-year-old woman underwent allogeneic bone marrow transplantation for acute lymphoblastic leukemia refractory to chemotherapy and subsequently developed invasive pulmonary aspergillosis, diagnosed by percutaneous needle biopsy. White blood cell count at the onset of symptoms was $0.1 \times 10^{9} / \mathrm{L}$. Immunosuppressive medications were cyclosporin A and methotrexate. Aspergillosis progressed despite amphotericin B (cumulative dose $4 \mathrm{~g}$ ). Itraconazole capsules, 400 $\mathrm{mg} /$ day via nasogastric tube, were added and amphotericin B was continued in addition until adequate absorption of itraconazole was documented with serum levels. The patient was receiving multiple other medications including ranitidine $150 \mathrm{mg} /$ day and antacids. She did not respond to treatment and died of disseminated aspergillosis two weeks after starting itraconazole, despite achieving persistently normal white blood cell and neutrophil counts. A serum itraconazole level four days after starting treatment was $0.6 \mu \mathrm{g} / \mathrm{mL}$.

\section{DISCUSSION}

Factors that result in low itraconazole levels do so either by reducing absorption or by increasing hepatic metabolism. Itraconazole is a weak base that is ionized only under conditions of low pH (17); gastric acidity is important for the drug to be soluble and this enhances absorption from the gastrointestinal tract. The absorption of itraconazole from capsules in the fasting state is only $40 \%$ of that obtained postprandially (18). Various classes of drugs, such as histamine receptor antagonists, antacids and proton pump inhibitors raise gastric $\mathrm{pH}$ and thus impair absorption of itraconazole. Didanosine (ddi) is formulated with buffers to prevent its destruction by gastric acid. Coadministration of ddi and itraconazole is not recommended (19), because of the likelihood that ddi interferes with absorption of the latter. If both drugs are used in a given patient, then itraconazole should be administered at least $2 \mathrm{~h}$ before ddi (20). Gastric achlorhydria impairs absorption of ketoconazole (21). Low serum itraconazole levels have been documented in patients with AIDS (22), in whom achlorhydria is known to be common (23).

Administration of itraconazole capsules through a nasogastric tube may be associated with low serum levels and treatment failure. Denning et al (6) described two patients with invasive aspergillosis in whom itraconazole capsules were administered through either a nasogastric tube or a gastrostomy tube. One patient had low serum levels and died of progressive disease; the other had a serum level of $0.6 \mu \mathrm{g} / \mathrm{mL}$ after five days despite a dose of $600 \mathrm{mg} /$ day. The use of interfering medications such as antacids was not mentioned in these two cases. Reduced absorption was attributed to "agglutination of particles clogging even a large-calibre tube". Information from the manufacturer suggests that in the nonacid environment of a nasogastric tube, the coating on individual itraconazole particles may agglutinate to form an insoluble complex that cannot be absorbed, regardless of any mechanical clogging of the tube (personal communication). If itraconazole must be administered through a nasogastric tube, the suspension form of the drug is recommended.

Itraconazole undergoes hepatic metabolism; little is excreted unchanged in urine $(17,24)$. Several drugs that induce hepatic metabolism have been noted to decrease itraconazole levels; these include rifampin, phenytoin, carbamazepine and possibly phenobarbital $(7,9,16,25,26)$. The interaction with rifampin may be problematic in AIDs patients, who frequently have con- 
current mycobacterial and fungal infections. The interaction with anticonvulsants may complicate treatment of fungal infections in patients with seizure disorders.

The main factor responsible for undetectable itraconazole levels in cases 1 and 2 appeared to be the coadministration of rifampin. Drug-induced achlorhydria and possibly nasogastric tube administration contributed to the low serum level in case 4 . Low serum itraconazole levels associated with AIDs likely accounted for the results obtained in case 3 , because levels did not rise significantly despite an increase in the itraconazole dose to $800 \mathrm{mg} /$ day and elimination of the omeprazole and antacids. Poor compliance is unlikely to have caused low serum itraconazole levels in the cases presented. Cases 1 and 2 denied noncompliance, and serum levels rose promptly after rifampin was stopped. Cases 3 and 4 had levels measured while receiving itraconazole in hospital.

Limited data are available regarding optimal serum itraconazole levels. Although there was significant interindividual variation, the mean peak serum level on 400 $\mathrm{mg} /$ day (standard dose for invasive mycoses) at steady state was $1.98 \mu \mathrm{g} / \mathrm{mL}$ in healthy volunteers (24). Levels are approximately 50\% lower in patients with AIDS (22). Denning et al (7) found that treatment failure of invasive aspergillosis was associated with steady state itraconazole levels below $7 \mu \mathrm{mol} / \mathrm{L}$ (5 $\mu \mathrm{g} / \mathrm{mL}$ ).

The consequences of low serum itraconazole levels due to enhanced metabolism are variable. Tucker et al (16) described five patients with cryptococcosis and mycobacterial disease treated with itraconazole and rifampin. Four patients responded despite decreased itraconazole levels, although two had a worsening of seborrheic dermatitis; one patient had worsening cryptococcal disease. The combination of itraconazole and rifampin was synergistic against cryptococcus in vitro. Reduced serum itraconazole levels have been associated with treatment failures against other fungal infections $(3,7,9,16,25,26)$ and failures of prophylaxis (27). In our patients, low itraconazole levels were associated with a relapse of disseminated histoplasmosis in one of

ACKNOWLEDGEMENTS: The authors thank Ian Patterson, BSc Pharm for his assistance, and Deborah Hamann-Trou for preparation of the manuscript.

\section{REFERENCES}

1. Gallis HA, Drew RH, Packard WW. Amphotericin B: 30 years of clinical experience. Rev Infect Dis 1990:12:308-29.

2. Saag MS. Dismukes WE. Azole antifungal agents: emphasis on new triazoles. Antimicrob Agents Chemother 1988:32:1-8.

3. Phillips P, Fetchick R. Weisman I, Foshee S, Graybill JR. Tolerance to and efficacy of itraconazole in treatment of systemic mycoses: preliminary results. Rev Infect Dis 1987:9(Suppl 1):S87-93.

4. Phillips P, Graybill JR, Fetchick R, Dunn JF. Adrenal response to corticotropin during therapy with two patients and development of superficial mycoses in both. The superficial mycoses resolved promptly in the patient whose rifampin was stopped. Two patients with invasive aspergillosis failed to respond to itraconazole, although neither had previously responded to amphotericin B, and one died within two weeks of starting itraconazole.

Certainly, factors other than low itraconazole levels likely played a role in treatment failure of the cases presented, including severity of immunocompromised state and underlying disease, and possibly the development of azole resistance, which has been well documented in human immunodeficiency virus-related thrush (28). There are no controlled trials of itraconazole in invasive aspergillosis $(6,7)$, and thus its efficacy is not clearly defined. Both patients with invasive aspergillosis received concomitant itraconazole and amphotericin B while itraconazole levels were pending. Amphotericin B was to be continued in these patients until adequate oral absorption of itraconazole was documented by serum levels. Although the mechanisms of action of polyenes and azoles suggest potential antagonism (29), the clinical significance is unknown. Recently in an aspergillosis animal model, Patterson et al (30) showed no evidence of antagonism with amphotericin plus fluconazole combination therapy.

\section{CONCLUSIONS}

We have described four patients in whom suboptimal to unmeasurable serum itraconazole levels were documented. Contributing factors included: concurrent therapy with drugs known to enhance itraconazole metabolism or drugs raising gastric $\mathrm{pH}$; and possibly the administration of the contents of itraconazole capsules through a nasogastric tube. Low levels were associated with relapse of disseminated histoplasmosis, development of superficial mycoses and treatment failure in invasive aspergillosis. We recommend that serum itraconazole levels be routinely measured when treating serious fungal infections in patients in whom potential interfering factors are identified.

itraconazole. Antimicrob Agents Chemother 1987:31:647-9.

5. Van Cutsem J, Van Gerven F, Janssen PAJ. Activity of orally, topically, and parenterally administered itraconazole in the treatment of superficial and deep mycoses: animal models. Rev Infect Dis 1987:9(Suppl 1):S15-32.

6. Denning DW, Tucker RM, Hanson LH, Stevens DA. Treatment of invasive aspergillosis with itraconazole. Am J Med 1989;86:791-800.

7. Denning DW, Follansbee SE, Scolaro M, Norris S, Edelstein H. Stevens DA. Pulmonary aspergillosis in the acquired immunodeficiency syndrome. N Engl J Med 1991;324:654-62.

8. Wheat LJ, Hafner RE, Wulfsohn M, et al. Prevention of relapse of histoplasmosis with itraconazole in patients with the acquired immunodeficiency syndrome. Ann Intern Med 1993;118:610-6. 
9. Denning DW. Tucker RM. Hanson LH, Hamilton JR, Stevens DA. Itraconazole therapy for cryptococcal meningitis and cryptococcosis. Arch Intern Med 1989:149:2301-8.

10. Ganer A, Arathoon E, Stevens DA. Initial experience in therapy for progressive mycoses with itraconazole, the first clinically studied triazole. Rev Infect Dis 1987;9(Suppl 1):S77-86.

11. Cauwenbergh G, De Doncker P, Stoops K, De Dier A-M, Goyvaerts H, Schuermans V. Itraconazole in the treatment of human mycoses: Review of three years of clinical experience. Rev Infect Dis 1987;9(Suppl 1):S146-52.

12. Graybill JR, Stevens DA, Galgiani JN, Dismukes WE, Cloud GA and the NAIAD Mycosis Study Group. Itraconazole treatment of coccidioidomycosis. Am J Med 1990;89:282-90.

13. Hawkins Van Tyle J. Ketoconazole; mechanism of action, spectrum of activity, pharmacokinetics, drug interactions adverse reactions and therapeutic use. Pharmacotherapy 1984:4:343-73.

14. Lazar JD, Wilner KD. Drug interactions with fluconazole. Rev Infect Dis 1990;12(Suppl 3):S327-33.

15. Englehard D, Stutman HR, Marks MI. Interaction of ketoconazole with rifampin and isoniazid. N Engl J Med 1984;311:1681-3.

16. Tucker RM, Denning DW, Hanson LH, et al. Interaction of azoles with rifampin, phenytoin, and carbamazepine: in vitro and clinical observations. Clin Infect Dis 1992;14:165-74.

17. Heykants J, Van Peer A, Van De Velde V, et al. The clinical pharmacokinetics of itraconazole: an overview. Mycoses 1989;32(Suppl 1):67-87.

18. Van Peer A, Woestenborghs R, Heykants J, Gasparini R, Cauwenbergh $\mathrm{G}$. The effects of food and dose on the oral systemic availability of itraconazole in healthy subjects. Eur J Clin Pharmacol 1989;36:423-6.

19. Moreno F, Hardin TC, Rinaldi MG, Graybill JA. Itraconazole-didanosine excipient interaction. JAMA 1993:269:1508. (Lett)

20. Bristol Laboratories. Videx (Didanosine) Product
Information. Evansville: Bristol Laboratories, 1992.

21. Lake-Bakaar G, Tom W, Lake-Bakaar D, et al. Gastropathy and ketoconazole malabsorption in the acquired immunodeficiency syndrome (AIDS). Ann Intern Med 1988;109:471-3.

22. Smith D, VandeVelde V, Woestenborghs R, Gazzard BG. The pharmacokinetics of oral itraconazole in AIDS patients. J Pharm Pharmacol 1992;44:618-9.

23. Lake-Bakaar G, Quadros E, Beidas S, et al. Gastric secretory failure in patients with the acquired immunodeficiency syndrome (AIDS). Ann Intern Med 1988; 109:502-4.

24. Hardin TC, Graybill JR, Fetchick R, Woestenborghs R, Rinaldi MG, Kuhn JG. Pharmacokinetics of itraconazole following oral administration to normal volunteers. Antimicrob Agents Chemother 1988;32:1310-3.

25. Blomley M, Teare EL, De Belder A, Thway Y, Weston M. Itraconazole and anti-tuberculosis drugs. Lancet 1990;336: 1255. (Lett)

26. Hay RJ, Clayton YM, Moore MK, Midgely G. An evaluation of itraconazole in the management of onychomycosis. $\mathrm{Br}$ J Dermatol 1988;1 19:359-66.

27. Tricot G, Joosten E, Boogaerts MA, Vande Pitte J, Cauwenbergh G. Ketoconazole vs itraconazole for antifungal prophylaxis in patients with severe granulocytopenia: preliminary results of two non-randomized trials. Rev Infect Dis 1987;9(Suppl 1):S94-9.

28. Dupont B, Improvisi L, Eliaszewicz M, Pialoux G. Resistance of Candida albicans to fluconazole in AIDS patients. 32nd Interscience Conference on Antimicrobial Agents and Chemotherapeutics. Anaheim, October 1992. (Abst 1203)

29. Schaffner A, Frick PG. The effect of ketoconazole on amphotericin B in a model of disseminated aspergillosis. $\mathrm{J}$ Infect Dis 1985;151:902-10.

30. Patterson TF, George D, Kordick D, Miniter P, Andrioke VT. The efficacy of combination therapy with fluconazole and amphotericin B in experimental invasive aspergillosis. 31st Interscience Conference on Antimicrobial Agents and Chemotherapy. Chicago, September 1991. (Abst 584) 


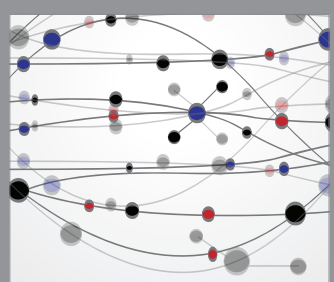

The Scientific World Journal
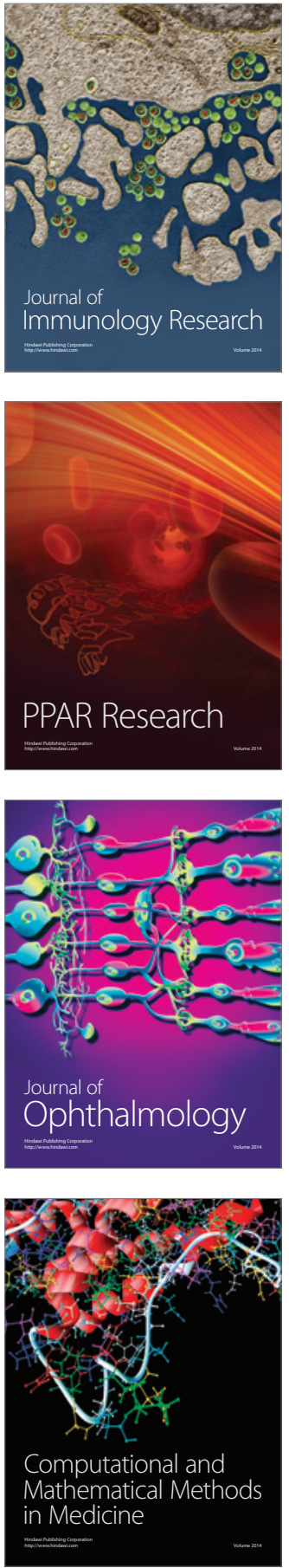

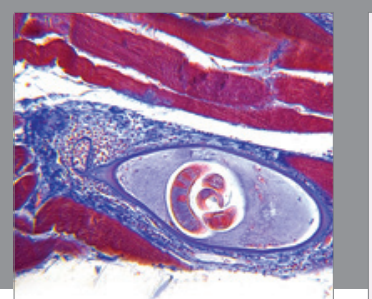

Gastroenterology Research and Practice

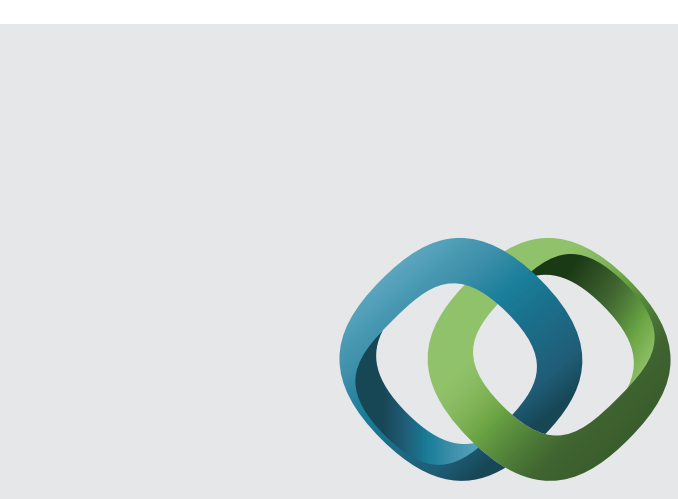

\section{Hindawi}

Submit your manuscripts at

http://www.hindawi.com
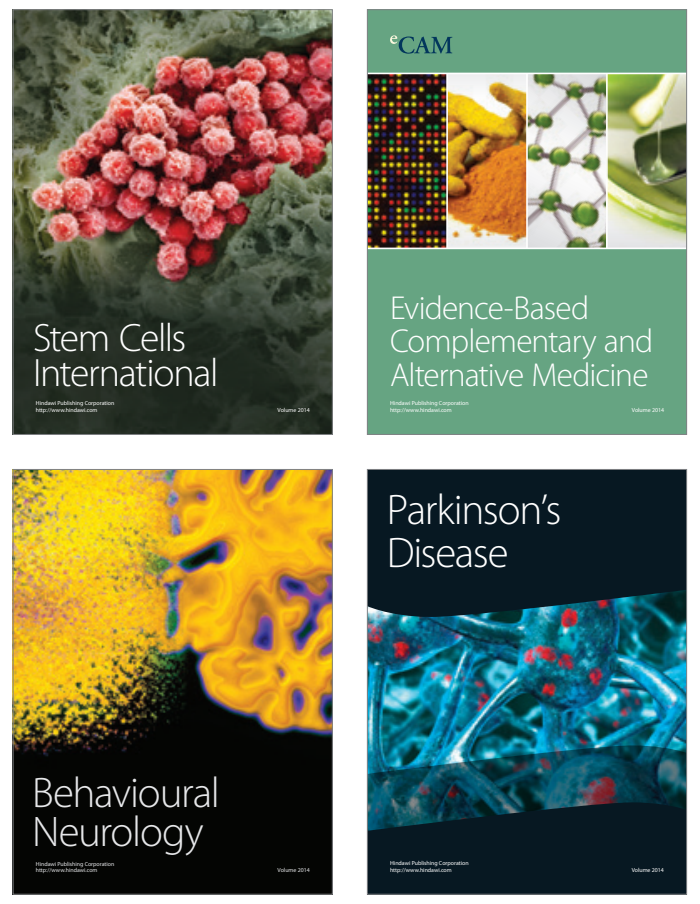
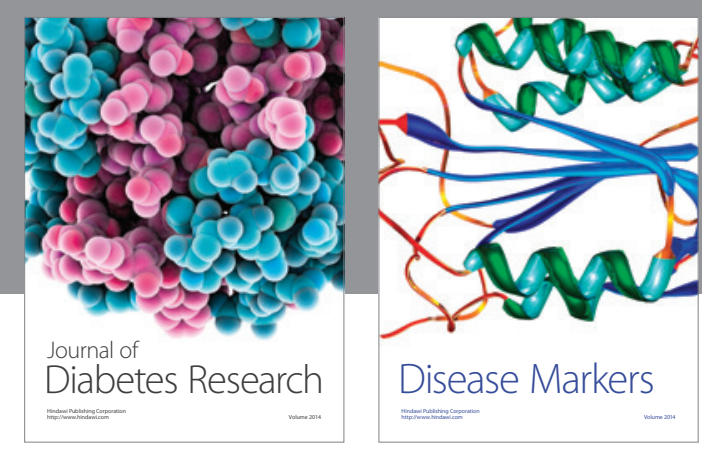

Disease Markers
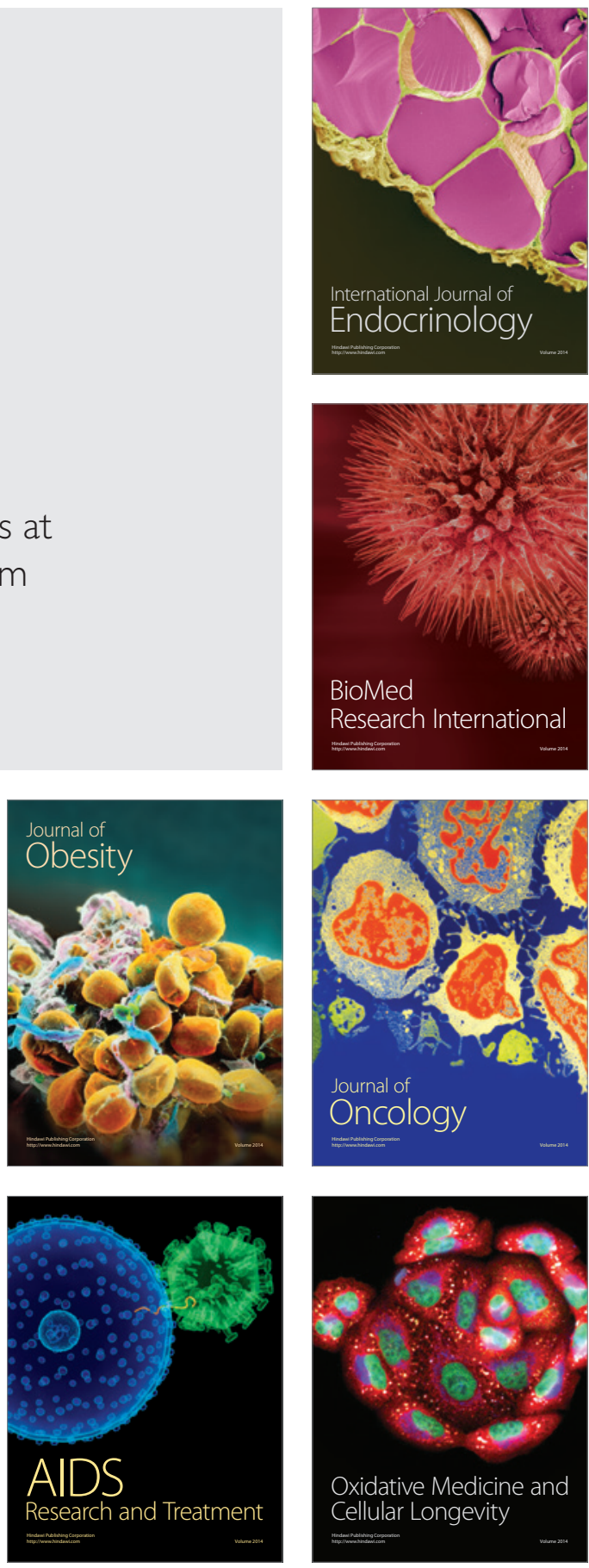